UCRL-ID-139526

\title{
Studies of Dynamic Properties of Shock Compressed Solids by in-situ Transient X-Ray Diffraction
}

H. Baldis, D. H. Kalantar, B. A. Remington, S. V. Weber, M. A. Meyers, J. S. Wark, G. Ravichadran, A. A. Hauer

June 26, 2000

U.S. Department of Energy

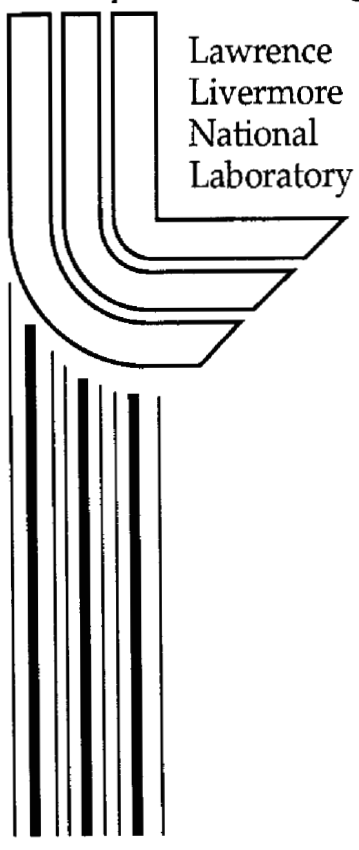




\section{DISCLAIMER}

This document was prepared as an account of work sponsored by an agency of the United States Government. Neither the United States Government nor the University of California nor any of their employees, makes any warranty, express or implied, or assumes any legal liability or responsibility for the accuracy, completeness, or usefulness of any information, apparatus, product, or process disclosed, or represents that its use would not infringe privately owned rights. Reference herein to any specific commercial product, process, or service by trade name, trademark, manufacturer, or otherwise, does not necessarily constitute or imply its endorsement, recommendation, or favoring by the United States Government or the University of California. The views and opinions of authors expressed herein do not necessarily state or reflect those of the United States Government or the University of California, and shall not be used for advertising or product endorsement purposes.

This work was performed under the auspices of the U. S. Department of Energy by the University of California, Lawrence Livermore National Laboratory under Contract No. W-7405-Eng-48.

This report has been reproduced directly from the best available copy.

Available electronically at http://www.doc.gov/bridge

Available for a processing fee to U.S. Department of Energy

And its contractors in paper from

U.S. Department of Energy

Office of Scientific and Technical Information

P.O. Box 62

Oak Ridge, TN 37831-0062

Telephone: (865) 576-8401

Facsimile: (865) 576-5728

E-mail: reports@adonis.osti.gov

Available for the sale to the public from

U.S. Department of Commerce

National Technical Information Service

5285 Port Royal Road

Springfield, VA 22161

Telephone: (800) 553-6847

Facsimile: (703) 605-6900

E-mail: orders@ntis.fedworld.gov

Online ordering: http://www.ntis.gov/ordering.htm

OR

Lawrence Livermore National Laboratory

Technical Information Department's Digital Library

http:/ / www.llnl.gov/tid/Library.html 


\title{
Studies of dynamic properties of shock compressed solids by in-situ transient $x$-ray diffraction
}

\author{
Hector Baldis - University of California at Davis \\ Daniel H. Kalantar, Bruce A. Remington, Stephen V. Weber - LLNL \\ Marc A. Meyers - University of California at San Diego \\ Justin S. Wark - University of Oxford \\ G. Ravichandran - California Insititute of Technology \\ Allan A. Hauer - Los Alamos National Laboratory
}

In the transient diffraction NLYF proposal we set forward a program of work to investigate the response of crystals to shock compression in regions of strain rates previously unexplored, in a coordinated experimental, computational, and analytical program. Time resolved $x$-ray diffraction was used to directly determine the lattice parameters of crystals during shock loading previously on the Nova and Trident laser facilities. Under this proposal we extended this work to exploit the multi-beam direct drive capability of the Omega laser facility to allow more extensive diagnostic access for measuring the lattice parameters both parallel and perpendicular to the shock front.

Under the NLUF Program in FY 99, we transitioned the dynamic diffraction experiments to the OMEGA facility. We developed a direct drive target configuration that uses a single beam to direct irradiate the surface of a thin crystal and 4 beams to irradiate a separate metal backlighter foil. Experiments were done with single crystal Si to demonstrate that the target design worked and that simultaneous measurements of compression both parallel and perpendicular to the shock propagation direction could be performed. We obtained simultaneous measurements of the (400) and (040) lattice planes during the period when a shock traveled through the crystal in the (100) direction. Follow-up experiments were done to demonstrate that this technique would work with thin metal crystals such as $\mathrm{Cu}$. Simultaneous measurements were made of the (200) and (020) lattice planes of $\mathrm{Cu}$ shocked along the (100) direction.

Future experiments (FY 00 and beyond) will be focussed on further studying the time resolved lattice response in $\mathrm{Cu}$ at a range of shock pressures. Additional techniques such as introducing a knife edge near the $x$-ray source are expected to provide information about the density of lattice dislocations created by the shock front. Results from these experiments will enable the separation of elastic and plastic components of strain in directions both parallel and perpendicular to the front at the strain rates of $10^{6}-10^{10} \mathrm{~s}^{-1}$. Current constitutive equations are highly speculative in this strain rate region. Time resolved measurements of lattice spacing at the shock front will establish plastic deformation rates independent of any model assumptions.

During FY 99, we performed a total of 24 laser experiments to demonstrate this technique on OMEGA and resolve diagnostic and timing issues.

The results from this work were presented at three conferences and several seminar presentations, and will also be described in future conference presentations.

This work was performed under the auspices of the U.S. Department of Energy by the University of California, Lawrence Livermore National Laboratory under Contract No. W-7405-Eng-48. 